\title{
Cytotoxic effect of nitric oxide on human hematological malignant cells ${ }^{\star}$
}

\author{
Michihiro Tsumori ${ }^{\bowtie}$, Junko Tanaka, Kunio Koshimura, Mikiko Kawaguchi, Yoshio \\ Murakami and Yuzuru Kato
}

First Division, Department of Medicine, Shimane Medical University, 89-1 Enya-cho, Izumo, 693-8501, Japan

Received: 10 September, 2001; revised: 29 January, 2002; accepted: 12 February, 2002

Key words: nitric oxide, lymphoma, leukemia, myeloma

\begin{abstract}
We investigated the cytotoxic effect of nitric oxide (NO) on primary culture of human hematological malignant cells. Sodium nitroprusside (SNP), an NO donor, had cytotoxic effects on the cells of some patients with malignant lymphoma (ML), acute myelocytic leukemia (AML) or chronic myelomonocytic leukemia (CMMoL), but not with multiple myeloma. Cultured cells from the ML patient remained sensitive to SNP after the cells became resistant to anti-cancer drugs. In contrast, the cells from the patients with AML and CMMoL became resistant to SNP while anti-cancer drugs remained effective. In samples of the cells of the patients with ML and AML, the number of CD3 positive lymphoma cell was decreased by SNP and the number of CD33 negative cells and normal B lymphocytes (CD19 positive cells) were increased. In the cells of the patient with ML, apoptosis was induced by SNP. SNP had no effect on lymphocytes of healthy volunteers. These results suggest that SNP had an anti-tumor effect on human hematological malignant cells.
\end{abstract}

Nitric oxide (NO) is a multifunctional molecule produced in a variety of mammalian cells. At physiological levels, NO is associated with neurotransmission and vasodilatation. At higher levels, NO has tumoricidal and bacteriocidal effects [1, 2]. In the cell-mediated immune responses, NO is produced in macrophages, neutrophils and lymphocytes [3-5]. Several lines of evidence indicate that NO has cytotoxic effects on human cell lines

\footnotetext{
${ }^{\star}$ Presented at the 8th International Symposium on Molecular Aspects of Chemotherapy, September, 2001, Gdańsk, Poland.

${ }^{\square}$ Address for all correspondence to Michihiro Tsumori, First Division, Department of Medicine, Shimane Medical University, 89-1 Enya-cho, Izumo 693-8501, Japan; phone: (81) 853202 184; fax: (81) 853238 650; e-mail: mtsumori@shimane-med.ac.jp

Abbreviations: AL, acute leukemia; ALL, acute lymphocytic leukemia; AML, acute myelocyte leukemia; CMMoL, chronic myelomonocytic leukemia; ML, malignant lymphoma; MM, multiple myeloma; NO, nitric oxide; SNP, sodium nitroprusside.
} 
from patients with leukemia or lymphoma [5-9]. These results raise the possibility that an NO donor might serve as a chemotherapeutic agent for hematological disorders. In the present study, we investigated the possibility of NO being a novel agent for the treatment of hematological malignancy using freshly isolated cells from patients with malignant hematological disorders.

\section{EXPERIMENTAL PROCEDURES}

Malignant cells were obtained from venous blood, bone marrow, ascites and lymphnodes of patients with malignant lymphoma (ML, $\mathrm{n}=6$ ), acute myelocytic leukemia (AML, $\mathrm{n}=5$ ), acute lymphocytic leukemia (ALL, $\mathrm{n}=1$ ), chronic myelomonocytic leukemia
(CMMoL, $\mathrm{n}=3$ ) and multiple myeloma (MM, $\mathrm{n}=2$ ), who were hospitalized in Shimane Medical University Hospital (Izumo, Japan) (Table 1). As normal control, lymphocytes were collected from venous blood of healthy volunteers $(n=3)$. The collected cells were washed with phosphate buffered saline and layered on Histopaque-1077 (Sigma-Aldrich, Tokyo, Japan). After centrifugation at 1500 r.p.m. for $30 \mathrm{~min}$, the cells present in the opaque interface were washed, plated $\left(2-4 \times 10^{6} / \mathrm{ml}\right)$ and cultured for 3-5 days before the experiments in RPMI 1640 medium supplemented with $10 \%$ fetal calf serum.

Sodium nitroprusside (SNP) or anti-cancer drugs were added to the cells which were then cultured for 3 days. Next, the total viable cell number was measured by the MTT assay [10] and subpopulations of viable cells were ana-

Table 1. Effect of SNP on viability of cells of patients with hematological disorders

\begin{tabular}{|c|c|c|c|c|c|c|c|}
\hline \multirow[t]{2}{*}{ Diagnosis } & & \multirow[t]{2}{*}{ Sex } & \multirow[t]{2}{*}{ Age (y) } & \multirow{2}{*}{ Character } & \multirow{2}{*}{$\begin{array}{l}\text { Source } \\
\text { of cells }\end{array}$} & \multicolumn{2}{|c|}{$\begin{array}{l}\text { Viability (\% of control) } \\
\text { (mean } \pm \text { S.E.) }\end{array}$} \\
\hline & & & & & & SNP $30 \mu \mathrm{M}$ & SNP $100 \mu \mathrm{M}$ \\
\hline \multirow{6}{*}{ Malignant lymphoma } & case 1 & M & 82 & B cell & ascites & $74.4 \pm 4.8^{*}$ & $42.3 \pm 1.2^{*}$ \\
\hline & case 2 & $\mathrm{~F}$ & 67 & B cell & $\mathrm{BM}$ & $156.8 \pm 24.3$ & $97.3 \pm 16.2$ \\
\hline & case 3 & $\mathrm{~F}$ & 80 & B cell & ascites & $72.7 \pm 3.0^{*}$ & $72.3 \pm 3.0^{*}$ \\
\hline & case 4 & $\mathrm{M}$ & 67 & $\mathrm{~T}$ cell & $\mathrm{LN}$ & $84.8 \pm 1.4^{*}$ & $73.7 \pm 1.2^{*}$ \\
\hline & case 5 & $\mathrm{~F}$ & 75 & $\mathrm{~T}$ cell & $\mathrm{LN}$ & $78.0 \pm 1.9^{*}$ & $72.8 \pm 1.8^{*}$ \\
\hline & case 6 & M & 70 & B cell & $\mathrm{LN}$ & $97.6 \pm 2.1$ & $94.1 \pm 2.6^{*}$ \\
\hline \multirow{6}{*}{ Acute leukemia } & case 7 & $\mathrm{~F}$ & 78 & AML(Ml) & PB & $108.0 \pm 3.4$ & $111.7 \pm 2.9$ \\
\hline & case 8 & $\mathrm{M}$ & 78 & AML(Ml) & $\mathrm{BM}$ & $107.6 \pm 5.9$ & $105.7 \pm 9.1$ \\
\hline & case 9 & $\mathrm{~F}$ & 33 & AML(M2) & $\mathrm{PB}$ & $100.9 \pm 4.6$ & $93.1 \pm 4.2$ \\
\hline & case 10 & $\mathrm{~F}$ & 17 & AML(M5a) & $\mathrm{BM}$ & $92.3 \pm 3.2$ & $89.2 \pm 4.3^{*}$ \\
\hline & case 11 & $\mathrm{~F}$ & 39 & AML(Ml) & BM & $120.6 \pm 7.7$ & $120.6 \pm 7.7$ \\
\hline & case 12 & $\mathrm{~F}$ & 72 & ALL(L2) & $\mathrm{BM}$ & $109.7 \pm 10.1$ & $100.5 \pm 2.9$ \\
\hline \multirow{3}{*}{$\begin{array}{l}\text { Chronic } \\
\text { myelomonocytic } \\
\text { leukemia }\end{array}$} & case 13 & M & 84 & & $\mathrm{BM}$ & $109.1 \pm 4.5$ & $107.6 \pm 3.5$ \\
\hline & case 14 & M & 82 & & $\mathrm{BM}$ & $81.8 \pm 3.4^{*}$ & $72.6 \pm 1.3^{*}$ \\
\hline & case 15 & M & 68 & & BM & $102.9 \pm 8.6$ & $104.9 \pm 5.7$ \\
\hline \multirow{2}{*}{ Multiple myeloma } & case 16 & $\mathrm{~F}$ & 78 & IgG- $\kappa$ & $\mathrm{BM}$ & $82.8 \pm 3.4^{*}$ & $93.1 \pm 3.4$ \\
\hline & case 17 & M & 68 & IgG- $\lambda$ & $\mathrm{BM}$ & $107.6 \pm 1.3$ & $99.0 \pm 10.8$ \\
\hline
\end{tabular}

Cell viability was estimated by the MTT assay. Cell viability was expressed as $\%$ of the corresponding control value. ${ }^{*} P<$ 0.05 vs. corresponding control value. BM: bone marrow; LN: lymphnode; PB: peripheral blood. 
lyzed by flow cytometry (Becton-Dickinson FACScan). Apoptosis of cells treated with SNP or anti-cancer drugs was estimated by the Apoptag in situ apoptosis detection kit (Intergen, NY, U.S.A.) according to the manufacturer's instruction.

All results were expressed as means \pm S.E.M. The significance of difference was evaluated by ANOVA and Fisher's test. A probability of $P<0.05$ was considered statistically significant.

\section{RESULTS}

The effect of SNP on cultured cells from the patients with malignant blood disorders is shown in Table 1. SNP reduced viability of the cells from 5 out of 6 patients with ML in a dose-related manner. SNP was effective with cells of one of 6 patients (AL, AML, ALL) with acute leukemia and one of 3 patients with CMMoL. In the patients with MM, $30 \mu \mathrm{M}$ SNP showed cytotoxicity with the cells of Case 16 but $100 \mu \mathrm{M}$ SNP had no effect. With Case 17, either dose of SNP had no effect on the cells. The lymphoma cells of Case 1 (ML) were sensitive to SNP even after becoming resistant to the anti-cancer drugs. In contrast, the cells of
Case 10 (AML) and Case 14 (CMMoL) became resistant to SNP, while remaining sensitive to the anti-cancer drugs (Fig. 1). Flow cytometry analysis revealed that SNP decreased the population of lymphoma cells (CD3 positive cells) of Case 5 (ML). In Case 4 (ML), SNP did not decrease the number of CD3 positive cells but increased that of normal lymphocytes (CD19 positive cells). In Case 10 (AML), SNP also increased the number of benign cells (CD33 negative cells) (Fig. 2). SNP induced apoptosis of the cells of Case 5 (ML) in a dose-related manner. SNP (100 $\mu \mathrm{M})$ showed cytotoxicity comparable to that of Ara-C (10 $\mu \mathrm{g} / \mathrm{ml})$ (Fig. 3). SNP was not cytotoxic for normal lymphocytes of healthy volunteers as studied by the MTT assay and flow cytometry (Fig. 4).

\section{DISCUSSION}

SNP showed cytotoxicity for the cells of ML patients independently cell type. The effect of SNP was most potent and persistent in the cells from the patients with ML, as compared with those with other hematological disorders. These results indicate that SNP is a promising candidate for an anti-lymphoma agent. However, out of 6 patients with $\mathrm{AL}$, the

Case $1(\mathrm{ML})$

Case 10 (AML)

Case14 (CMMoL)
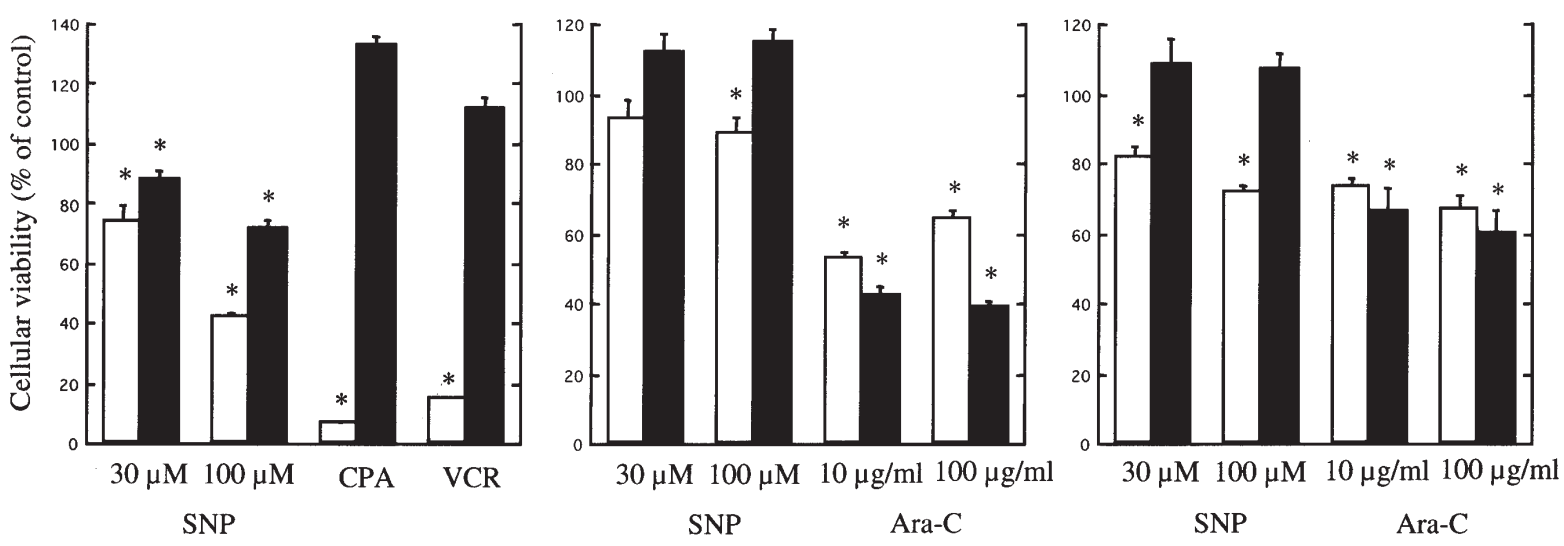

Figure 1. Effect of chemotherapy on cytotoxicity of SNP.

Cellular viability was expressed as \% of corresponding control value. Open column, pre-chemotherapy; closed column, after chemotherapy. CPA, cyclophosphamide $1600 \mu \mathrm{g} / \mathrm{ml}$. VCR, vincristine $6 \mu \mathrm{g} / \mathrm{ml}$; Ara-C, cytosine arabinoside. ${ }^{*} P<0.05$ vs. corresponding control value. 
Case 4 ML (T cell)

Case 5 ML (T cell)

Case 10 AML

A

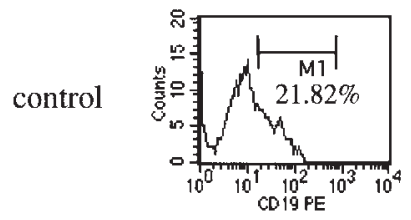

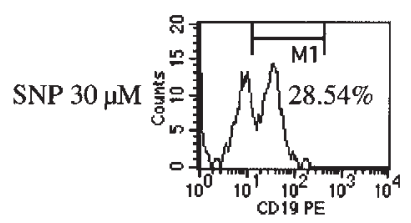

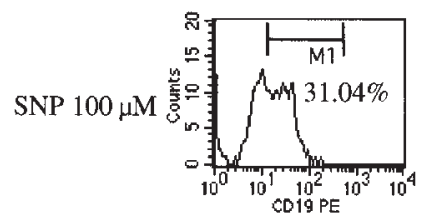

B
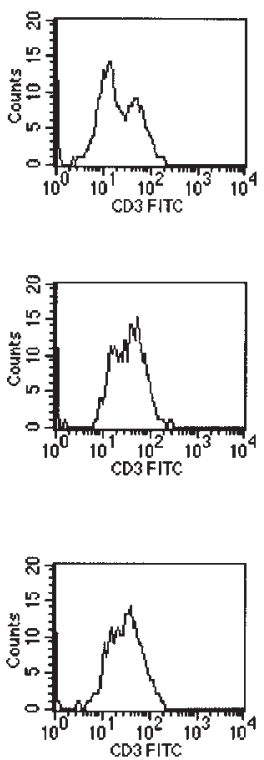

control

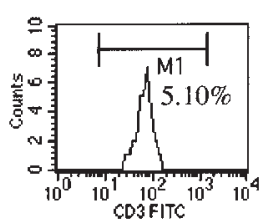

control
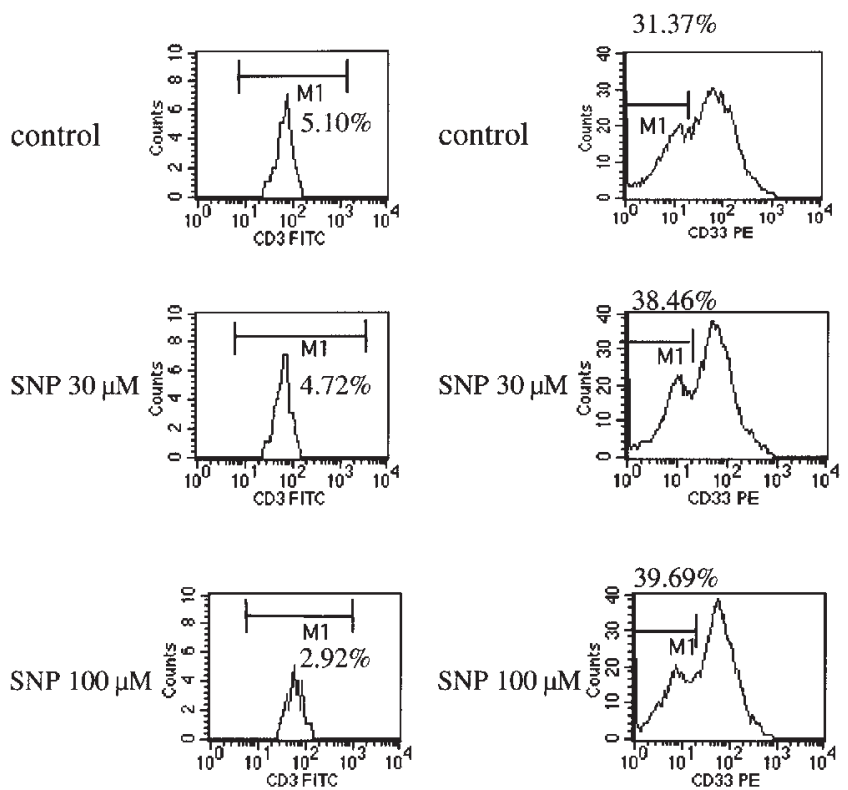

Figure 2. Flow cytometry analysis of cytotoxic effect of SNP.

Case 4 (ML T cell type): A, CD19-positive cells (normal B lymphocytes ) indicated by M1 (\% of analyzed cells); B, CD3-positive cells (T lymphocytes including lymphoma cells). Case 5 (ML T cell type): CD3-positive cells (lymphoma cells) indicated by M1 (\% of analyzed cells); lymphoma cells were selected by gating based on T cell subset CD3. Case 10 (AML): CD33 negative cells (non-leukemia cells) marked by M1 (\% of analyzed cells); CD33-positive cells (leukemia cells).

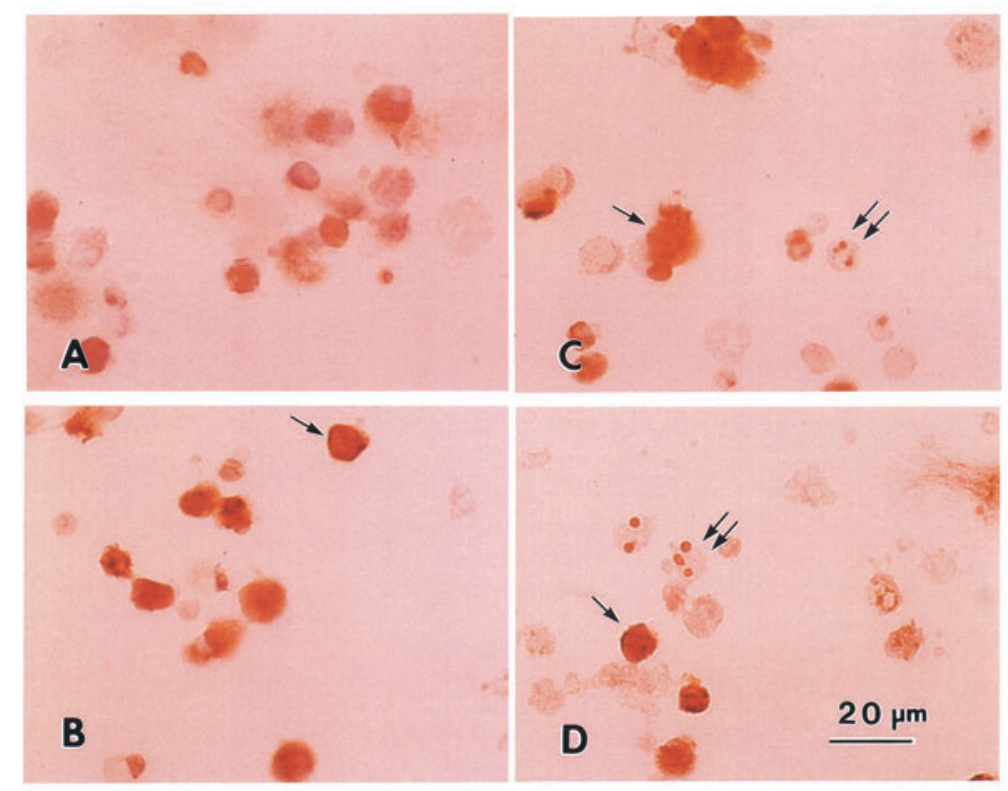

Figure 3. Induction of apoptosis by SNP.

Analysis of apoptosis was carried out in 4 cases (Cases 4, 5, 10 and 14). Representative data (case 5) are shown. Apoptotic cells are marked by single arrows (early stage of apoptosis) and double arrows (advanced stage of apoptosis). A, control cells; B, cells treated with $30 \mu \mathrm{M}$ SNP; C, cells treated with $100 \mu \mathrm{M} \mathrm{SNP;} \mathrm{D,} \mathrm{cells} \mathrm{treated} \mathrm{with}$ $10 \mu \mathrm{g} / \mathrm{ml}$ cytosine arabinoside (Ara-C). 
A. MTT assay

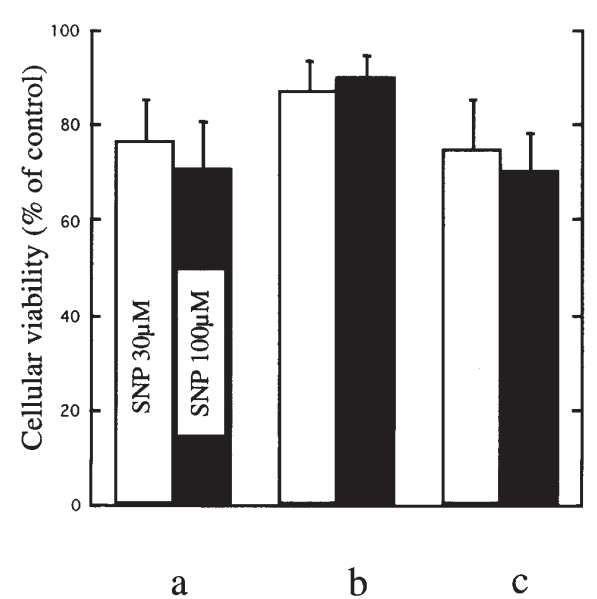

B. Flow cytometry
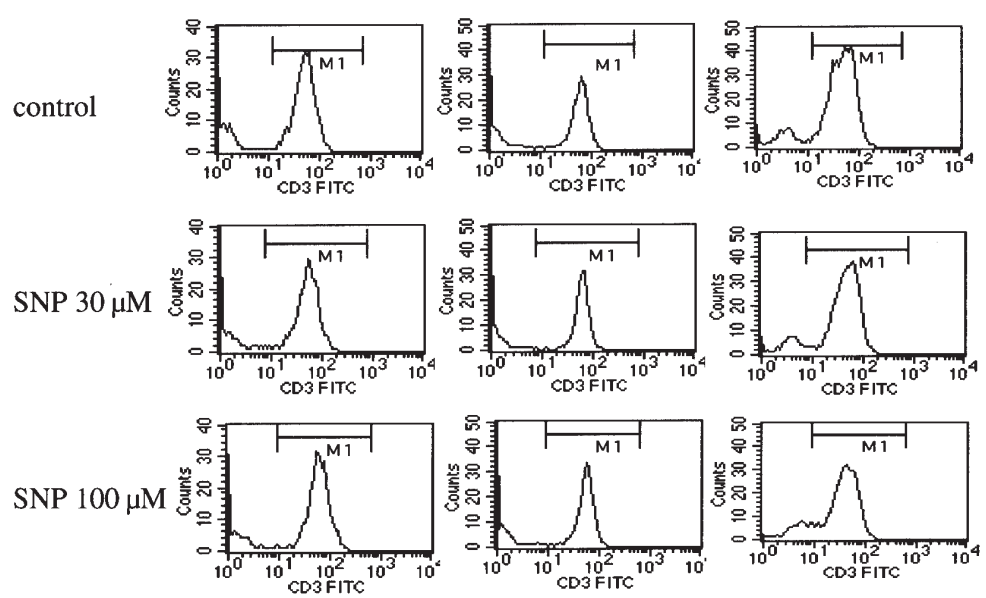

a

b

$\mathrm{c}$

Figure 4. Effect of SNP on lymphocytes of healthy volunteers (a-c) as studied by MTT assay (A) and flow cytometry (B).

A, Analysis by MTT assay. Cellular viability was expressed as \% of the control value. Open column, cells treated with $30 \mu \mathrm{M}$ SNP; closed column, cells treated with $100 \mu \mathrm{M}$ SNP. B, Analysis by flow cytometry; CD3 positive cells (T lymphocytes) marked by M1.

cytotoxic effect of SNP was observed in only one case (Case 10). The specificity of the effect of SNP on leukemia cells remains to be clarified. Case 10 was at the most advanced stage of the decrease among the patients with $\mathrm{AL}$ and the youngest among all the examined patients. In samples of cells from the patients with leukemia (Case 7-15), the cytotoxic effect of SNP was weak and transient, and cytotoxicity of SNP towards the cells of patients with MM was unclear. According to the results of flow cytometry, SNP was not toxic to normal cells either of the patients with hematological diseases or healthy people. Thus, it is possible that SNP induces much less adverse effects as compared with anti-cancer drugs. Taken together, the results suggest that SNP could be used as a novel anticancer agent.

We thank Mrs. A. Kanayama for technical assistance and Mrs. A. Kawakami for secretarial help.

\section{R E F E R E N C E S}

1. McCall, T. \& Vallance, P. (1992) Nitric oxide takes centre-stage with newly defined roles. Trends Pharmacol. Sci. 13, 1-6.

2. Shmidt, H.H.H.W. \& Walter, U. (1994) NO at work. Cell 78, 919-925.

3. Brüne, B., Götz, C., Messmer, U.K., Sandau, K., Hirvonen, M.-R. \& Lapetina, E.G. (1997) Superoxide formation and macrophage resistance to nitric oxide-mediated apoptosis. J. Biol. Chem. 272, 7253-7258.

4. Evance, T.J., Buttery, L.D.K., Carpenter, A., Springall, D.R., Polak, J.M. \& Cohen, J. (1996) Cytokine-treated human neutrophils contain inducible nitric oxide synthase that produces nitration of ingested bacteria. Proc. Natl. Acad. Sci. U.S.A. 93, 9553-9558.

5. Filep, J.G., Baron, C., Lachances, S., Perreault, C. \& Chan, J.S.D. (1996) Involvement of nitric oxide in target-cell lysis and DNA fragmentation induced by murine natural killer cells. Blood 87, 5136-5143. 
6. Dugas, N., Mossalayi, M.D., Calenda, A., Léotard, A., Bécherel, P., Mentz, F., Ouaaz, F., Arock, M., Debré, P., Donald, J. \& Dugas, B. (1996) Role of nitric oxide in the anti-tumoral effect of retinoic acid and 1,25-dihydroxyvitamine $\mathrm{D}_{3}$ on human promyelocytic leukemic cells. Blood 88, 3528-3534.

7. Jiang, H., Stewart, C.A., Fast, D.J. \& Leu, R.W. (1992) Tumor target-derived soluble factor synergies with IFN- $\gamma$ and IL-2 to activate macrophages for tumor necrosis factor and nitric oxide production to mediate cytotoxicity of the same target. J. Immunol. 149, 2137-2146.
8. Kwon, N.S., Stuehr, D.J. \& Nathan, C.F. (1991) Inhibition of tumor cell ribonucleotide reductase by macrophage-derived nitric oxide. J. Exp. Med. 174, 761-767.

9. Magrinat, G., Mason, S.N., Shami, P.J. \& Weinberg, J.B. (1992) Nitric oxide modulation of human leukemia cell differentiation and gene expression. Blood 80, 1880-1884.

10. Tanaka, J., Koshimura, K., Murakami, Y., Sohmiya, M., Yanaihara, N. \& Kato, Y. (1997) Neuronal protection from apoptosis by pituitary adenylate cyclase activating polypeptide. Regul. Pept. 72, 1-8. 